\title{
Use of New Direct-Acting Antivirals (DAAs) in Renal Transplant Patients Infected with Hepatitis C Virus: The First Experience in Sub-Saharan Africa
}

\author{
Tsevi $\mathrm{YM}^{1^{*}}$, Kane $\mathrm{Y}^{2}$, Guei $\mathrm{MC}^{3}$, Thioubou MA², Diallo $\mathrm{K}^{2}$ and Ackoundou N'Guessan KC ${ }^{3}$ \\ ${ }^{1}$ Department of Nephrology and Dialysis, Sylvanus Olympio University Teaching Hospital, University of Lome, Togo \\ ${ }^{2}$ Department of Nephrology and Internal Medicine, Assane Seck University, Ziguinchor, Senegal \\ ${ }^{3}$ Department of Nephrology, Dialysis and Organ Transplant, Yopougon Teaching Hospital, Felix Houphouet-Boigny University, Abidjan, Ivory Coast
}

Corresponding author: Tsevi Yawovi Mawufemo, Department of Nephrology and Dialysis, Sylvanus Olympio University Teaching Hospital, University of Lome, BP: 61842 Lome, Togo, Tel: 22890726289; E-mail: tseviclaude@gmail.com

Received date: Nov 04, 2017; Accepted date: Nov 09, 2017; Published date: Nov 14, 2017

Copyright: (C) 2017 Tsevi YM, et al. This is an open-access article distributed under the terms of the Creative Commons Attribution License, which permits unrestricted use, distribution, and reproduction in any medium, provided the original author and source are credited.

Keywords: Ivory Coast; Direct-acting antivirals; Kidney transplantation; Viral hepatitis C

\section{Commentary}

Hepatitis C virus (HCV) infection affects more than 200 million people worldwide and its prevalence is high in patients with end-stage renal disease, thus increasing challenges in renal transplant patients infected with HCV. In developed countries around 1.8 to $8 \%$ of renal transplant patients are infected with HCV $[1,2]$. Indeed, prior to the era of the new direct acting antivirals (DAAs), the treatment of hepatitis $\mathrm{C}$ was based solely on the combination of standard interferon and ribavirin. Treatment with interferon is not feasible in the renal transplant patient because of the risk of rejection that it can induce [3]. Since then, transplant patients have developed cirrhosis or hepatocellular carcinoma (HCC) charts. In these cases, only liver transplant can represent the last therapeutic alternative for many cases. With the advent of DAAs deemed effective [4], well tolerated and without significant interaction with immunosuppressant, it is high time to review these patients.

Thus, we report the first case of a Sub-Saharan African renal transplant patient living in Abidjan, Cote d'Ivoire who presented a decompensated cirrhosis chart on $\mathrm{HCV}$, in whom after treatment with $\mathrm{AAD}$, presented a favorable evolution of his clinical and biological condition. The purpose of the discussion was to demonstrate the contribution of DAAs in the management of HCV in a renal transplant patient from a resource-limited country formerly condemned to death. It was a renal transplant patient since June 2008 in India with a history of HCV contracted probably contracted before the start of dialysis, post-transplant diabetes, a long-term general condition impairment that has been hospitalized for increased impairment of the general condition with ascites, in whom the clinical and Para-clinical examination was in favor of a decompensated cirrhosis at stage CHILD B9 in relation to an HCV. In front of this chart, a treatment combining Sofosbuvir $400 \mathrm{mg} /$ lisispavir $90 \mathrm{mg}$ (1 tablet per day) for 12 weeks was undertaken because it was the treatment that was available at that time in the country. Under this treatment, the clinical evolution was marked by a rapid improvement of the general condition, a regression of ascites. The evolution under treatment of clinical and biological parameters is shown in Table 1.

Tolerance to anti-HCV therapy was excellent and no adverse effects were observed. Given the serious complications of chronic viral hepatitis $\mathrm{C}$ in the general population, in patients undergoing chronic hemodialysis and/or who have undergone transplantation and other factors in view of the socio-economic standard of living in our developing countries we recommend:

The cost of treatment subsidy allowing thus the treatment of a large number of patients.

The availability of reliable generic drugs of direct acting antivirals.

The implementation by medical practitioners of recommendations on the management of viral hepatitis $\mathrm{C}$ published by the World Health Organization (WHO).

\begin{tabular}{|c|c|c|c|c|c|}
\hline Parameters & Week 0 & Week 4 & Week 8 & Week 12 & SVR $^{*} 12$ \\
\hline \multicolumn{6}{|l|}{ General condition } \\
\hline Asthenia & Yes & Yes & No & No & No \\
\hline Nausea & Yes & No & No & No & No \\
\hline Ascite & Yes & Yes & No & No & No \\
\hline Headache & No & No & No & No & No \\
\hline HCV RNA (Ul/ml) & 524045 & $<15$ & $<15$ & $<15$ & $<15$ \\
\hline HCV RNA (Log) & 6.72 & $<1.2$ & $<1.2$ & $<1.2$ & $<1.2$ \\
\hline Platelets $\left(/ \mathrm{mm}^{3}\right)$ & 92000 & 80000 & 82000 & 96000 & 120000 \\
\hline $\begin{array}{l}\text { White Blood Cell } \\
(/ \mathrm{mm} 3)\end{array}$ & 4100 & 5000 & 48000 & 4800 & 4400 \\
\hline Neutrophil $\left(/ \mathrm{mm}^{3}\right)$ & 767 & 2575 & 1709 & 1800 & 1399 \\
\hline Hemoglobin (g/dl) & 10.2 & 10.9 & 9.5 & 10.2 & 11 \\
\hline AST (UI/I) & 196 & 46 & 43 & 44 & 45 \\
\hline ALT (UI/I) & 69 & 28 & 29 & 28 & 44 \\
\hline Creatinin (mg/l) & 13.7 & 15.6 & 14 & 13.9 & 15.6 \\
\hline $\begin{array}{l}\text { Rate of } \\
\text { prothrombin (\%) }\end{array}$ & 42 & 67 & 53 & 54 & 70 \\
\hline
\end{tabular}

Table 1: Evolution under treatment of clinical and biological parameters. 
Citation: Tsevi MY, Kane Y, Guei MC, Thioubou MA, Diallo K, et al. (2017) Use of New Direct-Acting Antivirals (DAAs) in Renal Transplant Patients Infected with Hepatitis C Virus: The First Experience in Sub-Saharan Africa. J Kidney 3: 153. doi:10.4172/2472-1220.1000153

Page 2 of 2

\section{References}

1. Scott DR, Wong JK, Spicer TS, Dent H, Mensah FK, et al. (2010) Adverse impact of hepatitis $\mathrm{C}$ virus infection on renal replacement therapy and renal transplant patients in Australia and New Zealand. Transplantation 90: 1165-1171.

2. Santos L, Alves R, Macario F, Parada B, Campos M, et al. (2009) Impact of hepatitis $\mathrm{B}$ and $\mathrm{C}$ virus infections on kidney transplantation: A single center experience. Transplant Proc 41: 880-882.
3. Rostaing L, Izopet J, Baron E, Duffaut M, Puel J, et al. (1995) Treatment of chronic hepatitis $\mathrm{C}$ with recombinant interferon alpha in kidney transplant recipients. Transplantation 59: 1426-1431.

4. Baid-Agrawal S, Pascual M, Moradpour D, Somasundaram R, Muche M (2014) Hepatitis $C$ virus infection and transplantation in 2014: What's new? Am J Transplant 14: 2206-2220. 